\title{
Persilangan 4 varietas kedelai (Glycine max L.) dalam rangka perakitan kedelai tahan kering
}

\author{
(Crossing 4 varieties of soybean (Glycine max L.) to get drought resistant varieties)
}

\author{
F. H. Utomo, B. A. Kristanto, F. Kusmiyati \\ Agroecotechnology, Department of Agriculture, Faculty of Animal and Agricultural Sciences, \\ Diponegoro University \\ Tembalang Campus, Semarang 50275 - Indonesia \\ Corresponding E-mail: frendyheri@gmail.com
}

\begin{abstract}
The purpose of this research was to study dialel crossing of 4 soybean varieties in order to get drought resistant varieties. The research used Completely Randomized Design with six crossing combination : Dering x Grobogan, Grobogan x Dering, Dering x Detam, Detam x Dering, Dering x Devon, and Devon x Dering. Each combination was repeated five times. Parameters observed were percentage of fertilization, number of seeds in pods, long of pods, weight of 10 seeds. Parameters were analyzed descriptively and heterosis was calculated. The research results showed that crossing between dering and devon had the highest percentage of fertilization. Crossing between dering and grobogan improved number of seed in pod, long of pods and weight of 10 seeds. The highest heterosis of seed number in pod, long of pods and weight of 10 seeds were resulted from crossing dering $\mathrm{x}$ devon, Dering x Grobogan, Grobogan x Dering, respectively.
\end{abstract}

Keywords : Crossing, genotype soybean, fist population

\begin{abstract}
ABSTRAK
Penelitian ini bertujuan untuk menyilangkan 4 varietas kedelai dalam rangka rangka perakitan kedelai tahan kering. Penelitian menggunakan rancangan acak lengkap (RAL) dengan 6 kombinasi persilangan : Dering x Grobogan, Grobogan x Dering, Dering x Detam, Detam x Dering, Dering x Devon, dan Devon $x$ Dering. Setiap kombinasi persilangan terdapat 5 kali ulangan. Parameter yang diamati adalah keberhasilan persilangan, jumlah biji dalam polong, panjang polong, berat 10 biji. Data yang diperoleh dianalisis secara deskriktif dan dihitung nilai heterosis. Hasil penelitian menunjukkan bahwa persentase keberhasilan persilangan tertinggi adalah Dering $\mathrm{x}$ Devon. Persilangan Dering $\mathrm{x}$ Grobogan mampu memperbaiki karakter panjang polong, jumlah biji tiap polong, dan berat 10 biji. Nilai duga heterosis tergolong tinggi dalam menghasilkan jumlah biji per polong adalah persilangan Dering $\mathrm{x}$ Devon, pada panjang polong adalah hasil persilangan Dering x Grobogan dan berat 10 biji pada persilangan Grobogan x Dering.
\end{abstract}

Kata Kunci : Persilangan, genotif kedelai, populasi awal

\section{PENDAHULUAN}

Kedelai merupakan salah satu komoditas pangan penting sebagai sumber bahan protein nabati. Kebutuhan kedelai setiap tahun mencapai
2 juta ton, sedangkan produksi kedelai dalam negeri hanya 0,8 juta ton per tahun, sehingga untuk memenuhinya diperlukan impor sebanyak 1,2 juta ton per tahun (Sa'diyah, 2016). Produksi kedelai yang rendah salah satunya disebabkan 
oleh kondisi lahan yang kering karena kekurangan air terutama saat musim kemarau. Usaha untuk meningkatkan produksi kedelai salah satunya menggunakan varietas unggul yang tahan terhadap kondisi kering dan berproduksi tinggi (Atam, 2009).

Keberhasilan pembentukan varietas unggul ditentukan oleh keragaman dari bahan genetik (Sitepu et al., 2015). Hal ini menunjukkan bahwa populasi dasar yang akan dievaluasi memiliki peranan penting terhadap pembentukan varietas. Semakin besar keragaman populasi dasar akan memperbesar peluang untuk memperoleh varietas unggul. Persilangan merupakan salah satu metode untuk memperluas keragaman genetik dan memperbanyak koleksi plasma nutfah dengan penyerbukan silang beberapa tetua yang memiliki susunan genetik yang berbeda untuk mendapatkan karakter yang diharapkan (Alia dan Wilia, 2010).

Hasil persilangan buatan pada tanaman kedelai dipengaruhi oleh karakter dari masingmasing varietas. Hal yang perlu diperhatikan dalam melakukan persilangan kedelai adalah keunggulan dari varietas yang akan disilangkan (Setyaningsih, 2011). Kedelai varietas Dering merupakan salah satu varietas unggul yang memiliki karakter toleran terhadap kondisi kekeringan namun memiliki ukuran biji kecil dengan potensi hasil 2,85 ton/ha. Kedelai Grobogan merupakan varietas kedelai yang memiliki karakter biji besar dengan potensi hasil 3,4 ton/ha. Kedelai Hitam merupakan salah satu verietas kedelai yang banyak dimanfaatkan dalam industri kecap dengan potensi hasil 3,4 ton/ha. Kedelai Devon merupakan varietas yang memiliki keunggulan kandungan isoflavon yang tinggi dan memliki potensi hasil 2,7 ton/ha (Balitkabi, 2015).

Kombinasi persilangan dari masing-masing tetua akan menghasilkan karakter dengan keragaman yang berbeda. Persilangan antara varietas Grobogan dengan kedelai hasil seleksi di tanah salin menunjukkan bahwa hasil polong berbiji 3 memiliki jumlah paling banyak (Lubis, 2015). Persilangan antara verietas grobogan dan anjasmoro menghasilkan bobot tiap biji $0,18 \mathrm{~g}$ hal itu disebabkan karena tetua grobogan memiliki karakter biji tergolong berukuran besar sehingga mampu mempebaiki bobot tiap biji dari varietas anjasmoro (Setyaningsih, 2011). Heterosis merupakan peningkatan yang terlihat pada dua galur varietas tertentu yang disilangkan. Peningkatan diukur dengan menghitung perbedaan F1 dengan nilai mid parent (rata rata tetua) atau dari nilai tetua yang superior (Suprayogi, 2016).

Penelitian ini bertujuan untuk menyilangkan kedelai Dering dengan varietas Grobogan, Detam dan Devon secara dialel sebagai salah satu tahapan untuk mendapatkan varietas kedelai tahan kering dan berproduksi tinggi. Manfaat Penelitian adalah memperoleh populasi dasar sebagai bahan untuk seleksi.

\section{MATERI DAN METODE}

Penelitian telah dilaksanakan pada tanggal 1 Februari - 1 Juni 2017 di green house dan Laboratorium Fisiologi dan Pemuliaan Tanaman Fakultas Peternakan dan Pertanian, Universitas Diponegoro, Semarang.

\section{Materi}

Bahan yang digunakan dalam penelitian ini adalah benih kedelai varietas Dering, varietas Grobogan, varietas Detam dan varietas Devon, tanah, sekam, pupuk kandang, air dan pupuk NPK $15: 15: 15$. Alat yang digunakan pada penelitian ini adalah cangkul, sekop, pot ukuran $30 \mathrm{~cm}$, penggaris pinset, timbangan analitik, gembor, sprayer, kamera, benang jahit, dan alat tulis.

\section{Metode}

Penelitian menggunakan rancangan acak lengkap (RAL) dengan kombinasi persilangan Dering x Grobogan, Grobogan x Dering, Dering x Detam, Detam $x$ Dering, Dering $x$ Devon, dan Devon $\mathrm{x}$ Dering. Setiap kombinasi persilangan terdapat 5 tanaman. Sehingga diperoleh 30 unit percobaan. Data yang diperoleh dilakukan analisis deskriptif dan dihitung nilai heterosisnya.

\section{Pelaksanaan penelitian}

Penelitian diawali dengan menyiapkan media yang terdiri dari tanah sekam dan pupuk kandang dengan perbandingan $1: 1: 1$ dicampur kemudian di masukkan kedalam pot yang memiliki diameter $30 \mathrm{~cm}$. Penanaman kedelai diatur sesuai waktu berbunga agar berbunga serentak. Kedelai varietas Dering ditanam paling awal. Dua hari setelah penanaman Dering ditanam varietas Detam dan Devon. Tujuh hari setelah penanaman Dering 
ditanam varietas Grobogan. Kedelai yang telah berbunga dilakukan proses persilangan. Pelaksanaan persilangan dilakukan dengan menyiapkan bunga betina yang masih kuncup kemudian dilakukan proses kastrasi, yaitu proses membersihkan bagian tanaman yang ada di sekitar bunga. Calon benangsari yang telah terlihat, kemudian dilakukan proses emaskulasi, yaitu proses pembuangan alat kelamin jantan pada tetua betina. Tahapan selanjutnya adalah menyiapkan bunga jantan dengan cara memilih bunga yang mekar dan segar. Bunga yang telah disiapkan dilakukan pengambilan polen kemudian proses penyerbukan dengan cara memasukkan polen yang telah diambil dan ditempelkan pada kepala putik.

\section{Parameter Pengamatan} adalah :

Parameter yang diamati dalam penelitian

(1) Keberhasilan persilangan, pengamatan didasarkan pada jumlah bunga yang mengalami pembuahan setelah disilangkan. Data yang diperoleh di hitung menggunakan rumus :

Keberhasilan $(\%)=$

(Jumlah bunga yang mengalami pembuahan)/ (Jumlah total bunga yang disilangkan) $\times 100 \%$

Hasil persilangan yang telah masak fisiologis dengan ciri kulit kedelai berwarna coklat dilakukan pemanenan dan pengamatan :

(2) Jumlah Biji dalam Polong, diamati dari banyaknya biji yang terdapat pada setiap polong yang dihasilkan melalui persilangan.

(3) Panjang Polong, diamati dengan mengukur panjang polong menggunakan penggaris.

(4) Berat Polong, diamati dengan cara menimbang polong yang telah dipanen dan kondisi kering.

(5) Berat 10 Biji di timbang kemudian di pilih acak sebanyak 10 biji untuk mengetahui prokduktivitas.

Data yang diperoleh dihitung nilai heterosis dan heterobiltosis dengan rumus :

$$
\begin{aligned}
& h M P(\%)=(\mu F 1-\mu M P) / \mu M P \times 100 \% \\
& h H P(\%)=(\mu F 1-\mu H P) / \mu H P \times 100 \%
\end{aligned}
$$

Keterangan :

hMP : heterosis rata-rata tetua (heterosis)

$\mu \mathrm{MP}$ : nilai tengah kedua tetua

hHP : heterosis rata-rata tetua tertinggi

(heterobeltiosis)

$\mu \mathrm{HP}$ : nilai tengah tetua tertinggi (high parent)

$\mu \mathrm{F} \quad$ : nilai tengah hasil penelitian

\section{HASIL DAN PEMBAHASAN}

\section{Keberhasilan Persilangan}

Hasil persilangan antara dialel varietas Dering dengan varietas Gobogan, Devon dan Detam menghasilkan persentasi keberhasilan yang berbeda (Tabel 1.) Berdasarkan hasil penelitian diatas dapat diketahui bahwa hasil persilangan kedelai tertinggi adalah persilangan antara varietas Dering x Devon yaitu 64,52\%, sedangkan tingkat

Tabel 1. Persentase Keberhasilan Persilangan

\begin{tabular}{lccc}
\hline \hline Persilangan & $\begin{array}{c}\text { Jumlah Bunga yang } \\
\text { disilangkan }\end{array}$ & $\begin{array}{c}\text { Jumlah Penyerbukan } \\
\text { yang Berhasil }\end{array}$ & $\begin{array}{c}\text { Persentase } \\
\text { Keberhasilan }\end{array}$ \\
\hline Dering x Grobogan & 25 & 10 & $-----\%$----- \\
Grobogan x Dering & 23 & 12 & 40,00 \\
Dering x Devon & 31 & 20 & 52,17 \\
Devon x Dering & 30 & 16 & 64,52 \\
Dering x Detam & 26 & 7 & 53,33 \\
Detam x Dering & 27 & 14 & 26,92 \\
\hline
\end{tabular}


keberhasilan persilangan yang paling rendah Dering $x$ Detam 26,92\%. Hasil persilangan tersebut dapat digolongkan memiliki keberhasilan yang baik. Penelitian yang telah dilakukan oleh Sitepu et al. (2015) persentase keberhasilan persilangan antara varietas Grobogan dan Anjasmoro $45-47 \%$. Besarnya persentase keberhasilan ditentukan oleh pembuahan serbuk sari pada kepala putik. Bunga yang terbuahi akan tetap segar, sedangkan yang tidak terbuahi akan kering dan gugur dalam waktu 3 hari setelah setelah penyerbukan ditandai dengan tidak rontoknya calon buah.

\section{Jumlah Biji dalam Polong}

Hasil persilangan antara varietas Dering sebagai tetua betina dengan varietas Gobogan, Devon dan Detam sebagai tetua jantan serta dialelnya menghasilkan jumlah biji dalam polong yang berbeda (Tabel 2). Berdasarkan data pada Tabel 2 dapat diketahui Varietas Dering sebagai tetua betina, persentase jumlah polong berbiji tiga

Tabel 2. Persentase Jumlah Biji dalam Polong Hasil Persilangan

\begin{tabular}{lcccc}
\hline \hline \multirow{2}{*}{ Persilangan } & \multirow{2}{*}{ Jumlah Polong } & \multicolumn{3}{c}{ Persentase Jumlah Polong } \\
\cline { 3 - 5 } & & Berbiji 1 & Berbiji 2 & Berbiji 3 \\
\hline \multirow{2}{*}{ Dering x Grobogan } & 10 & 0 & 70 & 30 \\
Grobogan x Dering & 12 & 33 & 58 & 8 \\
Dering x Devon & 20 & 35 & 30 & 35 \\
Devon x Dering & 16 & 19 & 38 & 44 \\
Dering x Detam & 7 & 50 & 33 & 17 \\
Detam x Dering & 14 & 31 & 54 & 15 \\
\hline Dering & 10 & 20 & 60 & 20 \\
Detam & 10 & 40 & 50 & 10 \\
Grobogan & 10 & 20 & 40 & 40 \\
Devon & 10 & 20 & 60 & 20 \\
\hline
\end{tabular}

persilangan. Hal ini sesuai dengan pendapat Setyaningsih (2011) yang menyatakan bahwa penyerbukan yang tidak di ikuti pembuahan menyebabkan bunga gugur sebelum menjadi buah. Rendahnya tingkat keberhasilan pada persilangan Dering $\mathrm{x}$ Detam diduga karena incompatible serbuk sari pada kepala putik dari verietas Dering. Rahajeng dan Rahayuningsih (2013) menyatakan terdapat 2 indikasi incompatible pada persilangan. Self incompatible yang terjadi pada persilangan karena interaksi stigma menolak polen untuk berkecambah ini menandakan yang mengendalikan pada persilangan tersebut adalah sporophitic incompatible. Sedangkan gagalnya polen membuahi ovum merupakan indikasi adanya sistem gametophitic incompatible. Menurut Syukur et al. (2015) keberhasilan persilangan dapat dilihat setelah satu minggu dapat ditingkatkan melaui penyilangan dengan varietas Grobogan dan Devon, masing-masing 20 $\%$ menjadi $30 \%$ dan $20 \%$ menjadi $35 \%$. Varietas Dering sebagai tetua jantan, dapat meningkatkan persentase jumlah polong berbiji 3 varietas Devon dari $30 \%$ menjadi $44 \%$. Varietas yang digunakan dalam persilangan akan mempengaruhi jumlah biji per polong. Berdasarkan Hasil penelitian Setyaningsih, (2011) menyebutkan bahwa persilangan antara verietas Grobogan dan Gepak Kuning belum bisa meningkatkan jumlah biji. Penelitian Lubis (2015) menyebutkan bahwa kombinasi persilangan antara varietas Grobogan dengan kedelai hasil seleksi di tanah salin menunjukkan bahwa hasil polong berbiji 3 memiliki jumlah paling banyak.

Nilai heterobeltiosis dan heterosis terbaik hasil persilangan adalah persilangan antara Devon 
$\mathrm{x}$ Dering yang memiliki nilai masing-masing $118,75 \%$. Nilai heterosis dan heterobeltiosis paling rendah adalah persilangan Dering $\mathrm{x}$ Grobogan masing-masing -100\% (Tabel 3.). polong dan hasil biji per tanaman. Jumlah biji per polong menggambarkan besarnya produksi kedelai. Semakin banyak jumlah biji pada setiap polong akan berbanding lurus dengan produksi

Tabel 3. Heterosis dan Heterobeltiosis Jumlah Biji dalam Polong

\begin{tabular}{lrrrrrr}
\hline \hline \multirow{2}{*}{ Persilangan } & \multicolumn{3}{c}{ Heterobeltiosis } & \multicolumn{3}{c}{ Heterosis } \\
\cline { 2 - 7 } & \multicolumn{1}{c}{ Berbiji 1 } & Berbiji 2 & Berbiji 3 & Berbiji 1 & Berbiji 2 & Berbiji 3 \\
\hline Dering x Grobogan & $-100,00$ & 16,67 & $-25,00$ & $-100,00$ & 40,00 & 0,00 \\
Grobogan x Dering & 66,67 & $-2,78$ & $-79,17$ & 66,67 & 16,67 & $-72,22$ \\
Dering x Devon & 75,00 & $-50,00$ & 75,00 & 75,00 & $-50,00$ & 75,00 \\
Devon x Dering & $-6,25$ & $-25,00$ & 118,75 & $-6,25$ & $-37,50$ & 118,75 \\
Dering x Detam & 25,00 & $-16,67$ & $-16,67$ & 66,67 & $-39,39$ & 11,11 \\
Detam x Dering & $-23,08$ & $-10,26$ & $-23,08$ & 2,56 & $-2,10$ & 2,56 \\
\hline
\end{tabular}

Polong yang dihasilkan pada persilangan Dering $\mathrm{x}$ Grobogan tidak menghasilkan polong berbiji 1, sehingga nilai heterosisnya rendah Nilai heterosis disebabkan oleh adanya akumulasi dari gen-gen dominan yang unggul dalam suatu genotip tanaman. Menurut Arif et al. (2012) Hasil persilangan yang menghasilkan nilai heterosis tinggi merupakan hasil persilangan terbaik. Ujianto et al. (2012) menambahkan semakin besar nilai duga heterosis maka semakin baik hasil persilangan yang ada. Hasil penelitian Zubair et al. (2010) 5 karakter hasil penelitian F1 menunjukkan heterosis yang tinggi untuk hasil jumlah polong per tanaman, jumlah biji per yang dihasilkan. Menurut Sitepu (2015) jumlah biji perpolong menggambarkan dari hasil biji yang akan diperoleh. Banyaknya biji pada setiap polong yang terbentuk merupakan salah satu parameter yang dijadikan sebagai pertimbangan dalam melakukan seleksi tanaman kedelai.

\section{Panjang Polong}

Hasil persilangan antara varietas Dering sebagai tetua betina dengan varietas Gobogan, Devon dan Detam sebagai tetua jantan serta dialelnya menghasilkan persentase panjang polong yang berbeda (Tabel 4). Penggunaan Grobogan sebagai tetua jantan dalam persilangan dengan

Tabel 4. Persentase Panjang Polong

\begin{tabular}{lcccc}
\hline \hline \multirow{2}{*}{ Kode } & \multirow{2}{*}{ Jumlah Polong } & \multicolumn{3}{c}{ Persentase Panjang Polong } \\
\cline { 3 - 5 } & & $-2,5 \mathrm{~cm}$ & $2,5-4,0 \mathrm{~cm}$ & $>4,0 \mathrm{~cm}$ \\
\hline & 10 & 0 & 30 & 70 \\
Dering x Grobogan & 12 & 8 & 25 & 67 \\
Grobogan x Dering & 20 & 15 & 60 & 25 \\
Dering x Devon & 16 & 13 & 50 & 38 \\
Devon x Dering & 7 & 29 & 43 & 29 \\
Dering x Detam & 14 & 23 & 69 & 8 \\
Detam x Dering & 10 & 20 & 50 & 30 \\
Dering & 10 & 30 & 50 & 30 \\
Detam & 10 & 10 & 30 & 60 \\
Grobogan & 10 & 20 & 40 & 40 \\
Devon & & &
\end{tabular}


Dering dapat meningkatkan panjang polong apabila dibandingkan dengan tetua Dering dan Grobogan. Penggunaan Dering sebagai tetua betina yang disilangkan dengan Devon dan Detam menurunkan panjang polong apabila dibandingkan dengan tetua Dering. Varietas Dering sebagai tetua
Detam x Dering menghasilkan heterosis masingmasing 38,64\%. Nilai Heterobeltiosis dan heterosis tertinggi dalam menghasilkan panjang polong $<2,5 \mathrm{~cm}$ pada persilangan Dering $\mathrm{x}$ Detama adalah $-4,76 \%$ dan 14,29 (Tabel 5).

Persilangan yang diduga mampu

Tabel 5. Heterosis dan Heterobeltiosis Panjang Polong

\begin{tabular}{llllllc}
\hline \hline \multirow{2}{*}{ Persilangan } & \multicolumn{3}{c}{ Heterobeltiosis } & \multicolumn{3}{c}{ Heterosis } \\
\cline { 2 - 7 } & $<2,5 \mathrm{~cm}$ & $2,5-4,0 \mathrm{~cm}$ & $>4,0 \mathrm{~cm}$ & $<2,5 \mathrm{~cm}$ & $2,5-4,0 \mathrm{~cm}$ & $>4,0 \mathrm{~cm}$ \\
\hline Dering x Grobogan & $-100,00$ & $-40,00$ & 16,67 & $-100,00$ & $-25,00$ & 55,56 \\
Grobogan x Dering & $-58,33$ & $-50,00$ & 11,11 & $-44,44$ & $-37,50$ & 48,15 \\
Dering x Devon & $-25,00$ & 20,00 & $-37,50$ & $-25,00$ & 33,33 & $-28,57$ \\
Devon x Dering & $-37,50$ & 0,00 & $-6,25$ & $-37,50$ & 11,11 & 7,14 \\
Dering x Detam & $-4,76$ & $-14,29$ & $-4,76$ & 14,29 & $-14,29$ & 14,29 \\
Detam x Dering & $-23,08$ & 38,46 & $-74,36$ & $-7,69$ & 38,46 & $-69,23$ \\
\hline
\end{tabular}

betina, persentase jumlah jumlah panjang polong $>4 \mathrm{~cm}$ yang berhasil di tingkatkan melalui persilangan dengan varietas Grobogan, dari $40 \%$ menjadi $70 \%$. Ukuran biji dari varietas Grobogan tergolong biji besar sehingga karakter tersebut akan terbawa saat dilakukan persilangan dan terjadi pembuahan dengan varietas Dering. Menurut Setyaningsih (2011), faktor yang mempengaruhi panjang polong adalah karakter yang diwariskan oleh tetuanya. Varietas grobogan digolongkan memiliki ukuran biji besar. Sehingga, besarnya biji akan berpengaruh pada panjang polong. Penelitian yang dilakukan oleh Ujianto (2012) menjelaskan bahwa persilangan antar spesies kacang tunggak yang memiliki diameter polong kecil disilangkan dengan kacang panjang yang memiliki diameter polong besar menghasilkan rata lebih dari tetuanya. Sulistyo (2015), kedelai varietas grobogan memiliki bobot 100 biji 19,8 g. Varietas grobogan yang dijadikan tetua pada proses persilangan membawa karakter biji berukuran besar sehingga diwariskan pada generasi selanjutnya.

Nilai heterobeltiosis dan heterosis dari hasil persilangan tertinggi dalam menghasilkan polong yang memiliki panjang $>4 \mathrm{~cm}$ adalah persilangan Dering x Grobogan masing-masing 16,67\% dan $55,56 \%$. Heterobeltiosis dan heterosis tertinggi pada panjang polong $2,5-4,0 \mathrm{~cm}$ persilangan menghasilkan dan memperbaiki panjang polong ditunjukkan pada nilai heterosis yang tinggi adalah Dering x Grobogan. Nilai terbaik dalam menghasilkan panjang polong $>4 \mathrm{~cm}$ adalah persilangan Dering x Grobogan. Menurut Arif et al. (2012) Hasil persilangan yang memnghasilkan nilai heterosis tinggi merupakan hasil persilangan terbaik. Ujianto et al. (2012) menambahkan semakin besar nilai duga heterosis maka semakin baik hasil persilangan yang ada. Terjadinya heterosis diebabkan oleh ekspresi gen dari kedua tetua yang diturunkan melalui persilangan. Meneurut (Rubiyo dan Sudarsono, 2011) menyatakan bahwa terjadinya proses heterosis disebabkan karena aksi dan interaksi gen-gen dominan yang unggul terkumpul dalam satu genotipe F1 hasil persilangan kedua tetuanya.

\section{Berat 10 Biji}

Hasil persilangan antara varietas Dering sebagai tetua betina dengan varietas Gobogan, Devon dan Detam sebagai tetua jantan serta dialelnya menghasilkan berat 10 biji yang berbeda (Tabel 6). Hasil pengamatan yang telah dilakukan terhadap berat 10 biji menunjukkan bahwa persilangan dialel antara varietas Dering yang disilangkan dengan varietas Grobogan, Detam dan Devon menghasilkan berat yang beragam. Persilangan antara Dering sebagai tetua betina 
Tabel 6. Berat 10 Biji

\begin{tabular}{lc}
\hline \multicolumn{1}{c}{ Persilangan } & Berat 10 Biji \\
\hline & ------ g -------- \\
Dering x Grobogan & 1,21 \\
Grobogan x Dering & 2,19 \\
Dering x Devon & 1,17 \\
Devon x Dering & 1,38 \\
Dering x Detam & 1.25 \\
Detam x Dering & 1,37 \\
\hline Dering & 1,15 \\
Detam & 1.42 \\
Grobogan & 2,20 \\
Devon & 1,41 \\
\hline
\end{tabular}

yang disilangkan dengan varietas Grobogan mampu meningkatkan berat 10 biji dari $1,18 \mathrm{~g}$ menjadi 1,21 g. Penggunaan tetua Devon dan Detam sebagai tetua jantan yang disilangkan dengan tetua betina Dering belum mampu meningkatkan berat 10 biji.

Perbedaan hasil persilangan dipengaruh oleh kombinasi antara tetua jantan dan betina. Tetua yang memiliki pengaruh besar dalam produksi biji ditentukan oleh tetua betina. Hal tersebut dikarenakan bakal buah terdapat di dalam tetua betina. Penelitian yang telah dilakukan oleh Setyaningsih (2008) menyebutkan bahwa persilangan antara verietas grobogan dan anjasmoro menghasilkan bobot tiap biji $0,18 \mathrm{~g}$. Tetua grobogan memiliki karakter biji tergolong berukuran besar sehingga mampu mempebaiki bobot 10 biji dari varietas anjasmoro. Sitepu (2015) menambahkan bahwa tetua betina memiliki pengaruh lebih tingii dibandingkan dengan tetua jantan. Hal tersebut dikarenakan bakal buah dari persilangan berasal dari tetua betina. Tetua jantan memiliki pengaruh namun tidak besar, karena serbuk sari digunakan untuk membuahi tetua betina.

Nilai heterobeltiosis dan heterosis terbaik pada hasil persilangan Grobogan $x$ Dering masing-masing $-0,45 \%$ dan $30,75 \%$ (Tabel 7). Menurut Arif et al. (2012) Hasil persilangan dalam menghasilkan nilai heterosis tinggi merupakan hasil persilangan terbaik. Proses persilangan belum memiliki pengaruh yang besar terhadap ukuran biji dari masing-masing kombinasi. Hasil heterosis dan heterobeltiosis paling rendah pada kombinasi persilangan Dering $x$ Grobogan. Hal ini disebabkan karena karakter biji dari verietas Dering memiliki ukuran yang paling kecil dibandingkan varietas lain sehingga

Tabel 7. Heterosis dan Heterobeltiosis Berat 10 Biji

\begin{tabular}{lcc}
\hline \hline Persilangan & Heterobeltiosis & Heterosis \\
\hline Dering x Grobogan & $-45,00$ & $-27,76$ \\
Grobogan x Dering & $-0,45$ & 30,75 \\
Dering x Devon & $-17,02$ & $-8,59$ \\
Devon x Dering & $-2,13$ & 7,81 \\
Dering x Detam & $-11,97$ & $-2,72$ \\
Detam x Dering & $-3,52$ & 6,61 \\
\hline
\end{tabular}


nilai heterobeltiosis dan heterosisnya juga rendah. Hasil persilangan Dering $x$ Grobogan memiliki nilai yang paling kecil dan paling negatif. Menurut hasil penelitian Sa'diyah (2016) menyebutkan bahwa semakin negatif nilai heterosis yang dihasilkan, maka semakin besar pula sifat pewarisan ketahanan yang dihasilkan dari kombinasi persilangan yang bersangkutan. Syukur et al. (2015) menambahkan bahwa faktor yang mempengaruhi karakter adalah kedua tetua yaitu jantan dan betina. Penggabungan kedua karakter yang dibawa oleh tetua jantan dan tetua betina akan tetap mempertahankan karakter yang dibawa sehingga keduanya akan dapat berpisah kembali secara utuh pada saat pembentukan gamet.

\section{KESIMPULAN}

Kesimpulan dari penelitian ini adalah setiap kombinasi persilangan akan menghasilkan karakter yang berbeda-beda. Persilangan Dering x Grobogan mampu memperbaiki karakter panjang polong, jumlah biji tiap polong, dan berat 10 biji. Nilai duga heterosis tergolong tinggi dalam menghasilkan jumlah biji per polong adalah persilangan Dering x Devon, pada panjang polong adalah hasil persilangan Dering $\mathrm{x}$ Grobogan dan berat 10 biji pada persilangan Grobogan x Dering.

\section{DAFTAR PUSTAKA}

Alia, Y., dan W. Wilia. 2011. Persilangan empat varietas kedelai dalam rangka penyediaan populasi awal untuk seleksi. J. Penelitian Universitas Jambi Seri Sains. 13 (1) : $39-$ 42.

Arif, A. B., Sujiprihati, dan M. Syukur. 2012. Pendugaan heterosis dan heterobeltiosis pada enam genotipe cabai menggunakan analisis silang dialel. J. Hort 22 (2) : 103 110

Atman. 2009. Strategi peningkatan produksi kedelai di Indonesia. J. Ilmiah Tambua 8 (1): 39-45

Balitkabi. 2015. Deskripsi Varietas Unggul Kacang-kacangan. Malang.
Lubis, N. A., Rosmayati dan D. S. Hanafiah. 2015. Persilangan genotipe genotipe kedelai (Glycine max L. Merrill.) hasil seleksi pada tanah salin dengan tetua betina varietas Grobogan. Jurnal Online Agroekoteknologi. 3(1) : $291-298$.

Rubiyo, Trikoekoesoemaningtyas, dan Sudarsono. 2011. Pendugaan daya gabung dan heterosis ketahanan tanaman kakao (Theobroma cacaoL.) terhadap penyakit busuk buah (Phytophthora palmivora). J. Littri. 17(3) : 124-131.

Sa'diyah, N., M. A, Hasriyadi, P. Ria, J. Risa, dan B. Maimun. 2016. Heritabilitas, nisbah potensi, dan heterosis ketahanan kedelai (Glycine Max [L.] Merrill) terhadapsoybean Mosaic Virus. J. HPT Tropika. 16 (1) : 17 24.

Setyaningsih, F. H. 2011. Persilangan Dialel pada Enam Varietas untuk Peningkatan Hasil Kedelai (Glycine Max (L) Merril). Fakultas Pertanian. Universitas Sebelas Maret. Surakarta. (Skripsi)

Sitepu, M. B., Rosmayati, dan M. K, Bangun. 2015. Persilangan genotipe-genotipe kedelai (Glycine $\max$ L. Merrill.) hasil seleksi pada tanah salin dengan tetua betina varietas anjasmoro. Jurnal Online Agroekoteknologi. 3 (1) : $257-263$.

Sulistyo, A. 2015. Seleksi kedelai populasi F2 hasil persilangan antara galur kedelai toleran kutu kebul dengan varietas Grobogan. Pros Sem Nas Masy Biodiv Indon. Volume 1(5) : 1142-1146.

Suprayogi, B. 2016. Pendugaan Nilai Heterosis dan Evaluasi Daya Hasil Mentimun Hibrida Persilangan Dua Varietas. Fakultas Pertanian. Universitas Lampung. Lampung. (Skripsi).

Syukur, M., S. Sujiprihatni, dan R. Yuniati. 2015. Teknik Pemuliaan Tanaman. Penebar Swadaya. Jakarta. 
Ujianto, L., Idris dan U. M. Yakop. 2012. Kajian heritabilitas dan heterosis pada persilangan antara kacang tunggak dengan kacang panjang. Buletin Plasma Nutfah. 18 (1) : 9 17.
Zubair, M., S.U. Ajmal, and S. Ali. 2010. Heterosis for yield related attributes in mungbean (Vigna radiata (L.) Wilczek). Pak. J. Bot. 42(12) : 3209-3214. 